\title{
Minimalisasi Penyebaran COVID 19 Pada Lingkungan Pesantren, Sekolah dan Puskesmas Melalui Bantuan Alat Wastafel Portabel
}

\author{
Azwar Hayat $^{*}$, Andi Erwin $E^{1}$. Putra, Lukmanul Hakim Arma ${ }^{1}$, Hairul Arsyad ${ }^{1}$, Muhammad \\ Syahid $^{1}$, Novriany Amaliyah ${ }^{1}$, Gerard A. Duma ${ }^{1}$, dan Asriadi Sakka ${ }^{1}$ \\ Departemen Teknik Mesin, Fakultas Teknik Universitas Hasanuddin ${ }^{1}$ \\ azwar.hayat@unhas.ac.id*
}

\begin{abstract}
Abstrak
Tingkat penyebaran Covid-19 di Indonesia masih terus mengalami peningkatan, jumlah masyarakat yang telah terkonfirmasi positif Covid-19 sebesar 55.092 orang dengan jumlah kematian sebesar 2.805 orang. Sulawesi Selatan menjadi peringkat ke-tiga wilayah provinsi dengan tingkat penyebaran yang tinggi dengan angka terkonfirmasi positif Covid-19 sebesar 4.995 orang dan jumlah yang meninggal sebesar 164 orang (data pertanggal 29 Juni 2020). Untuk mengurangi tingginya penyebaran di Provinsi Sulawesi Selatan berbagai tindakan pencegahan telah dilakukan. Salah satu upaya pencegahan yang paling efektif adalah dengan senantiasa mencuci tangan menggunakan sabun. Sabun terbukti secara efektif dapat merusak lapisan protein bagian luar dari Covid-19 dan pada kahirnya dapat membunih virus tersebut. Dalam pengabdian masyarakat ini bertujuan memberikan bantuan alat wastafel portabel dan sekaligus sosialisasi pencegahan penyebaran Covid-19 baik melalui banner di pesantren, puskesmas dan sekolah pada area kabupaten Gowa. Kegiatan ini akan dilaksanakan sebagai upaya pencegahan penyebaran Covid-19 di pesantren, sekolah dan puskesmas dalam memasuki masa "new normal" saat ini.
\end{abstract}

Kata Kunci: COVID-19; Pesantren; Cuci tangan; Wastafel; Portabel.

\begin{abstract}
The level of the spread of covid-19 in Indonesia continues to increase, the number of people who have been confirmed positive for Covid-19 is 55,092 people with a death toll of 2,805. South Sulawesi is in the third rank of a province with a high level of spread with a positive confirmed number of Covid-19 of 4,995 people and a death toll of 164 people (data as of 29 June 2020). To reduce the high spread in South Sulawesi province, various preventive measures have been taken. One of the most effective preventive measures is to always wash your hands with soap. Soap has been shown to effectively damage the outer protein layer of Covid-19 and in the end can kill the virus. In this community service, the aim is to provide portable sink equipment assistance and at the same time to socialize the prevention of the spread of Covid-19 through banners at Islamic boarding schools, puskesmas and schools in the Gowa district area. This activity will be carried out as an effort to prevent the spread of Covid-19 in Islamic boarding schools, schools and health centers in entering the current "new normal" period.
\end{abstract}

Keywords: COVID-19; Islamic School; Wash hand; Sink; Portable.

\section{Pendahuluan}

Pandemik Covid-19 saat ini menjadi persoalan kesehatan utama disetiap negara. Tingginya tingkat penyebaran dan jumlah kasus kematian diberbagai negara menjadikan Covid-19 sebagai persoalan yang membutuhkan penanganan serius baik pada segi pengobatan maupun pada aspek penyebarannya. Saat ini tingkat penyebaran Covid-19 di Indonesia sebaanyak 55.092 orang dengan jumlah kematian sebesar 2.805 orang (data BNPB pertanggal 29 Juni 2020). Sebagai negara kepulauan dengan cakupan wilayah yang sangat luas menjadi faktor yang mempengaruhi tingkat ancaman epidemiologis yang berbeda dengan negara lain. 
Seperti halnya dengan negara lainnya, Indonesia telah mengambil sejumlah tindakan dan upaya yang diperlukan untuk mengatasi persoalan penyebaran Covid-19. Pembentukan gugus tugas percepatan penanganan Covid-19 dibawah koordinasi BNPB talah dibuat dengan perwakilan yang ada disetiap daerah. Selain pembentukan gugus tugas tersebut, tindakan penting lainnya yang dapat dilakukan adalah mencegah penyebaran Covid-19 adalah dengan bekerjasama antara pemerintah baik pada tingkat pusat, daerah hingga tingkat kelurahan. Kementrian Kesehatan telah menerbitkan Pedoman Pencegahan dan Pengendalian Covid-19 dalam rangka untuk mengedukasi masyarakat tentang pentingnya pencegahan dan penyebaran yang dapat dilakukan dengan menjaga jarak, menggunakan masker dan senantiasa membersihkan tangan menggunakan sabun.

Provinsi Sulawesi Selatan telah ditetapkan sebagai provinsi dengan tingkat penyebaran Covid-19 yang tinggi berdasarkan data penduduk yang terkonfirmasi positif Covid-19. Bahkan data pada awal bulan juni meperlihatkan jumlah pertambahan positif Covid-19 sudah lebih dari 100 orang perhari. Meskipun beberapa waktu yang lalu pemerintah provinsi Sulawesi Selatan telah mengambil kebijakan pembatasan sosial berskala besar (PSBB) namun belum bisa meminimalisasi tingkat penyebaran (Indtimes.com, 2020). Berdasarkan data pusat informasi Covid-19 (https://covid19.sulselprov.go.id/, 2020), jumlah penduduk yang terkonfirmasi positif tertinggi berada pada kota Makassar dan Kabupaten Gowa. Dari data Sulsel tanggap Covid-19 per 29 Juni diperoleh data untuk provinsi sulawesi selatan jumlah orang positif sebesar 4995 orang dan jumlah pasien yang meninggal sebanyak 164 orang. Dari data tersebut sulawesi selatan menjadi provinsi ketiga terbesar penyebaran Covid-19. Tingginya tingkat penyebaran tersebut sudah didominasi oleh penularan lokal dari pada kasus impor.

Dalam kondisi "New normal" saat ini, yang perlu menjadi perhatian utama adalah meningkatkan kesadaran masyarakat akan pentingnya menjaga kebersihan pribadi dengan rajin memcuci tangan dengan sabun, memakai masker, menjaga jarak dan mematuhi protocol kesehatan yang telah dikeluarkan oleh pemerintah. Berdasarkan hal ini maka kami merencakanan melakukan kegiatan pengabdian kepada masyarakat dalam bentuk bantuan alat cuci tangan (wastafel portabel) ditempat umum yaitu Pesantren, Sekolah dan Puskesmas yang berada didaerah kabupaten Gowa yang merupakan lokasi kampus Teknik Universitas Hasanuddin. Diharapkan bantuan ini mampu membantu menurunkan angka penyebaran Covid-19 di kabupaten Gowa.

\section{Latar Belakang Teori}

Pada penghujung tahun 2019, Wuhan yang merupakan salah satu kota berkembang di Tiongkok mengalami pandemi virus korona baru yang membunuh lebih dari delapan belas ratus dan menginfeksi lebih dari tujuh puluh ribu individu dalam lima puluh hari pertama pandemi. Virus ini merukapan bagian dari kelompok $b$ virus corona. Virus baru tersebut dinamai Wuhan coronavirus atau novel 2019 coronavirus (2019-nCov) oleh para peneliti Cina. Corona virus adalah keluarga besar virus yang umum pada manusia dan berbagai spesies hewan, termasuk unta, sapi, kucing, dan kelelawar. Ada banyak jenis virus korona pada manusia, termasuk beberapa yang umumnya menyebabkan penyakit saluran pernapasan bagian atas ringan (Cui, 2019). COVID-19 adalah penyakit baru, yang disebabkan oleh virus korona baru (atau baru) yang sebelumnya tidak pernah terlihat pada manusia. Virus korona hewan jarang menginfeksi manusia dan kemudian menyebar antar manusia. Ini terjadi dengan dua virus korona sebelumnya, MERS-CoV dan SARS-CoV. Virus SARS-CoV-2 adalah virus corona beta, seperti MERS-CoV dan SARS-CoV (Lai C, 2020). Ketiga virus ini berasal dari kelelawar. Urutan dari 
pasien A.S. mirip dengan yang awalnya diposting China, menunjukkan kemungkinan kemunculan tunggal virus ini baru-baru ini dari reservoir hewan. Namun, sumber pasti dari virus ini belum teridentifikasi. Dalam sejarah, SRAS-CoV (2003) menginfeksi 8.098 orang dengan angka kematian 9\%, di 26 negara di dunia, di sisi lain, COVID-19 menginfeksi 37 juta individu dengan angka kematian 2,7\% di seluruh dunia, sampai tanggal penulisan ini pada bulan Oktober 2020 .

Sampai saat ini vaksin untuk pencegahan Covid-19 masih dalam tahapan uji klinis. Pengobatan yang pasti juga belum ditemukan secara tepat. Yang dapat dilakukan dalam mencegah penyebaran Covid-19 adalah melakukan protocol Kesehatan secara ketat dan disiplin untuk meminimalisasi penyebaran virus tersebut. Jika COVID-19 menyebar di lingkungan kita, tetaplah menjaga diri dengan melakukan beberapa tindakan pencegahan sederhana, seperti menjaga jarak secara fisik, mengenakan masker, menjaga ruangan berventilasi baik, menghindari keramaian, rajin mencuci tangan, dan batuk ke siku atau tisu.

Meskipun terlihat sederhana, mencuci tangan yang benar tetap merupakan cara paling efektif untuk menghilangkan kuman dan bakteri berbahaya dari tangan kita. Ini mencegah penyebaran penyakit dan menjaga lingkungan Anda tetap aman, steril, dan bersih. Ada banyak cara yang mudah untuk menjaga kebersihan tangan. Metode umum yang digunakan di banyak tempat kerja adalah penggunaan sabun dan air yang cukup atau pembersih berbasis alkohol yang baik ketika air tidak mudah diakses. Akan lebih mudah untuk mencuci tangan dengan lebih serius ketika kita mengetahui manfaat dari menjaga tangan tetap bersih sesering mungkin dan juga menjaga kebersihan lingkungan dengan benar.

Penelitian menunjukkan bahwa kedua tangan harus digosok bersama setidaknya selama 30 detik menggunakan sabun. Setelah ini selesai, tangan bisa dibilas dengan air mengalir pada keran. Mencuci tangan yang baik membutuhkan fokus pada telapak tangan, punggung tangan dan juga ujung jari. Di sini, kami telah menyoroti langkah-langkah yang tepat untuk mencuci tangan agar bebas dari bakteri berbahaya. Hal mudah ini akan mengurang penyebaran virus pada masyarakat.

\section{Metode}

\subsection{Tahapan Persiapan}

Tahapan persiapan terdiri atas kegiatan sebagai berikut:

a) Koordinasi dan sosialisasi awal dengan mitra kegiatan yaitu Pondok Pesantren, Sekolah dan Puskesmas yang menjadi obyek dari kegiatan pengabdian masyarakat ini.

b) Pembuatan Wastafel portabel yang akan disumbangkan kepada mitra sebagai sarana pendukung dalam mencapai tujuan pengabdian kepada masyarakat ini.

c) Pembuatan bahan sosialisasi berupa banner untuk sarana edukasi pentingnya mencuci tangan dalam pencegahan penyebaran virus corona.

Kegiatan pengabdian ini melibatkan beberapa mitra. Mitra pertama yaitu Pesantren, Sekolah dan Puskesmasyang berada di kecamatan Pallangga kabupaten Gowa. Mitra kedua adalah Masyarakat Kabupaten Gowa sebagai masyarakat umum (Konsumen) yang akan diedukasi tentang bahaya dan pentingnya protocol Kesehatan dalam mencegah penyebaran secara luas Covid-19. Mitra pertama akan membatu memfasilitasi penempatan alat Wastafel portabel yang akan dijadihak sebagai produk hibah pada kegiatan pengabdian ini dan mitra kedua akan menghadirkan anggota masyarakat untuk tercapainya tujuan pengabdian masyarakat ini. 
Dilakukan persiapkan bahan-bahan yang akan dibuat menjadi wastafel portabel terdiri dari, besi siku, plat baja, wadah stainless steel, tangki air, pipa, selang dsb. Selain itu juga persiapan peralatan perakitan mesin las, mesin potong pelat, mesin tekuk dan toolset lainnya. Adapun bentuk wastafel yang akan dibuat seperti pada gambar 1 .

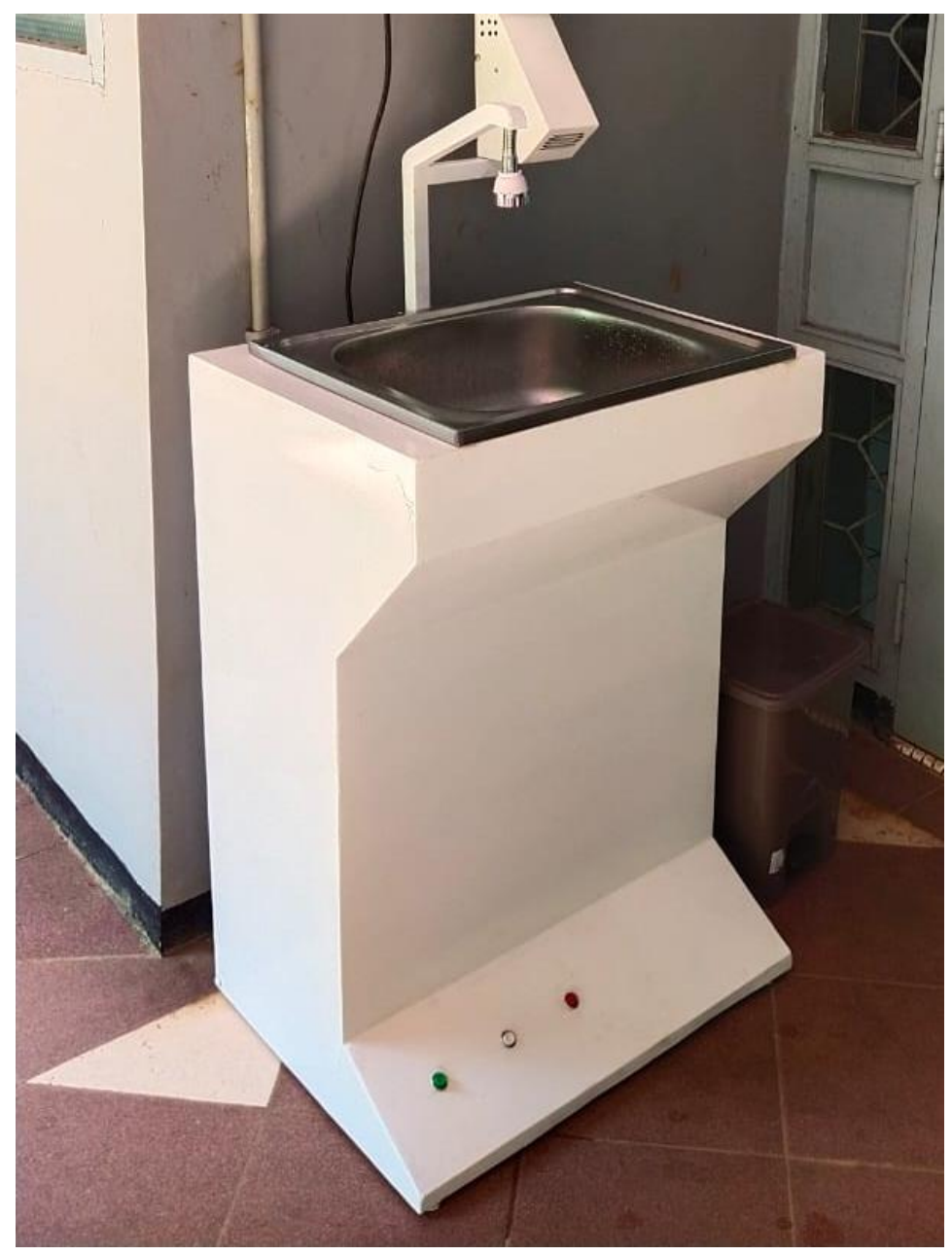

Gambar 1. Bentuk Wastafel Portabel

\subsection{Tahap pelaksanaan}

Pelaksanaan kegiatan dilakukan dengan memberikan sarana pendukung dalam pencegahan penyebaran Covid-19 berupa wastafel portabel yang dapat digunakan di lingkungan Pondok Pesantren, Sekolah dan Puskesmas. Dilakukan pula sosialisasi Gerakan Masyarakat Hidup Sehat (Germas) dengan pemasangan banner cara mencuci tangan yang baik dan benar.

\section{Hasil dan Diskusi}

Tahap pelaksanaan kegiatan dilakukan pada tanggal 6 Oktober 2020 bertempat di Pondok Pesantren Yatama Mandiri BKMT, TK Mustika, dan Puskesmas Pembantu (PUSTU) Yatama Kecamatan Pallangga, Kabupaten Gowa Sulawesi Selatan. 
Bantuan alat wastafel portabel diterima langsung oleh Ketua Yayasan Pondok Pesantren Yatama, Ibu Hj. Nuraisah Hafidz. Bantuan alat cuci tangan ini akan sangat membantu meminimalisir terjadinya penyebaran COVID-19 dari tamu yang berkunjung ke Pondok Pesantren. Alat cuci tangan portable yang diletakkan didepan aula pintu masuk memudahkan tamu untuk melakukan cuci tangan.
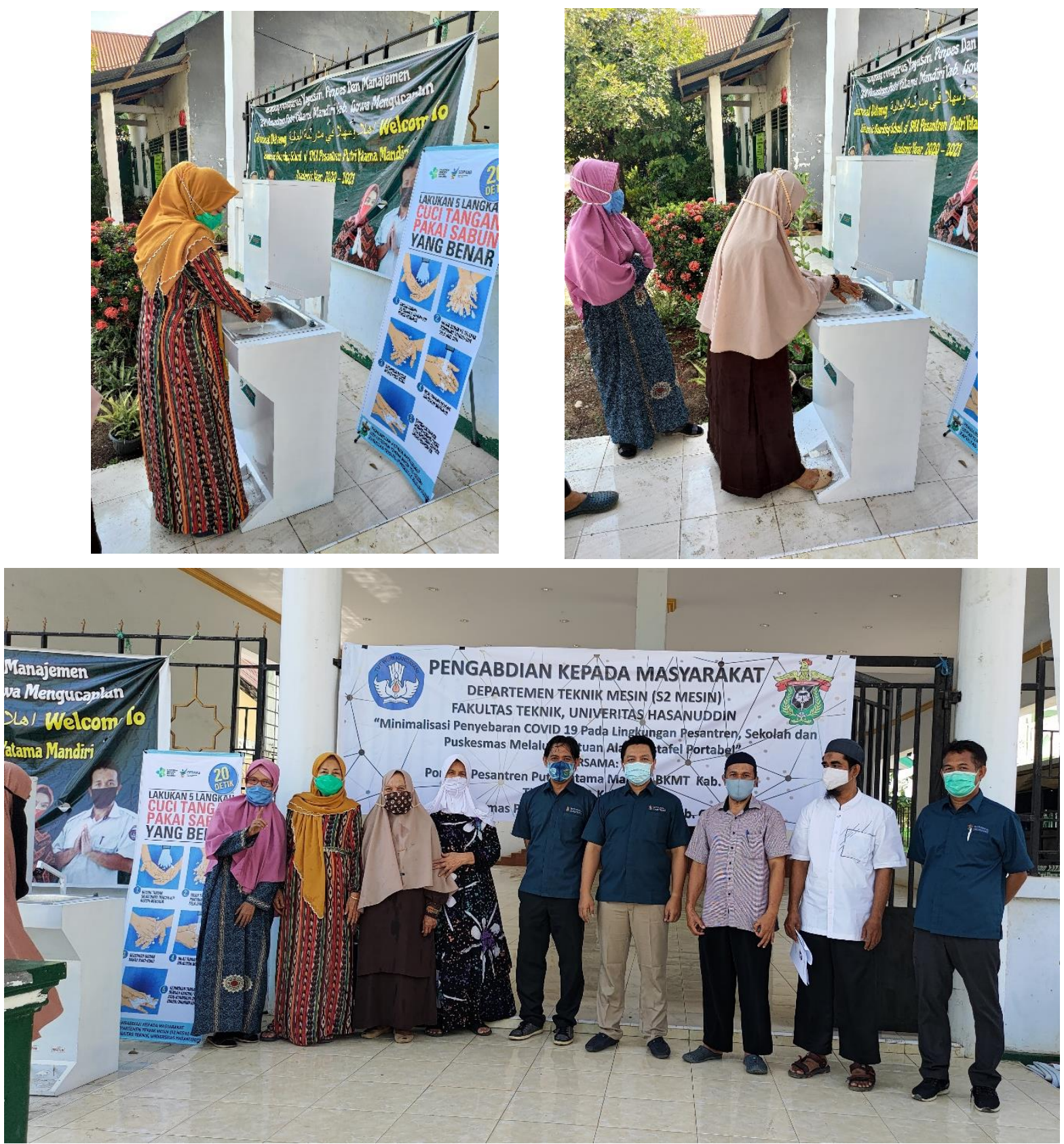

Gambar 2. Penyerahan dan Penggunaan wastafel portabel pada Pondok Pesantren 
Bantuan alat cuci tangan portable juga diberikan kepada TK Mustika dan Puskesmas Pembantu Yatama yang berlokasi berdekatan dengan pondok pesantren Yatama. Sumbangan alat diterima langsung oleh Kepala Sekolah TK Mustika, Hj. Fatmawati, SE dan Kepala Pustu Yatama, dr. Tri Oktaviani. Edukasi mencuci tangan sangat diperlukan ditumbuhkan di anak-anak kita sejak dini. Dengan bantuan alat cuci tangan otomatis yang kami terima ini siswa akan mampu memperaktekkan cara mencuci tangan yang benar dan menyebarkan pengetahuan ini kepada keluarganya. Pihak Pustu juga sangat terbantu dengan adanya bantuan alat cuci tangan ini. Pustu sangat membutuhkan alat seperti ini karena masyarakat yang sakit akan mengunjungi puskesmas dan dirasa sangat perlu ada alat cuci tangan yang praktis dan tanpa sentuhan tangan dalam pencegahan penyebaran Covid-19.
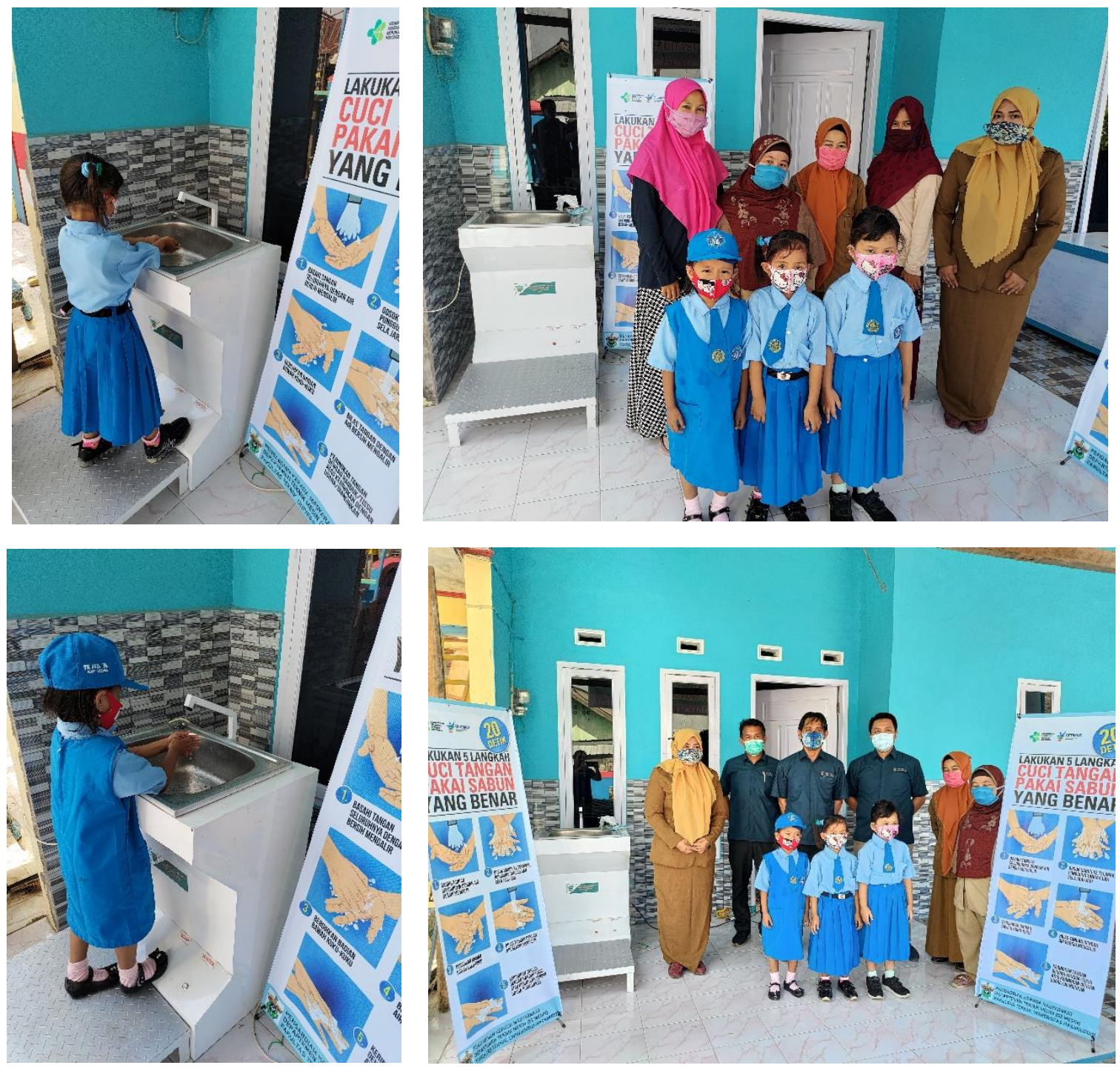

Gambar 3. Penyerahan dan Penggunaan wastafel portabel pada TK. 

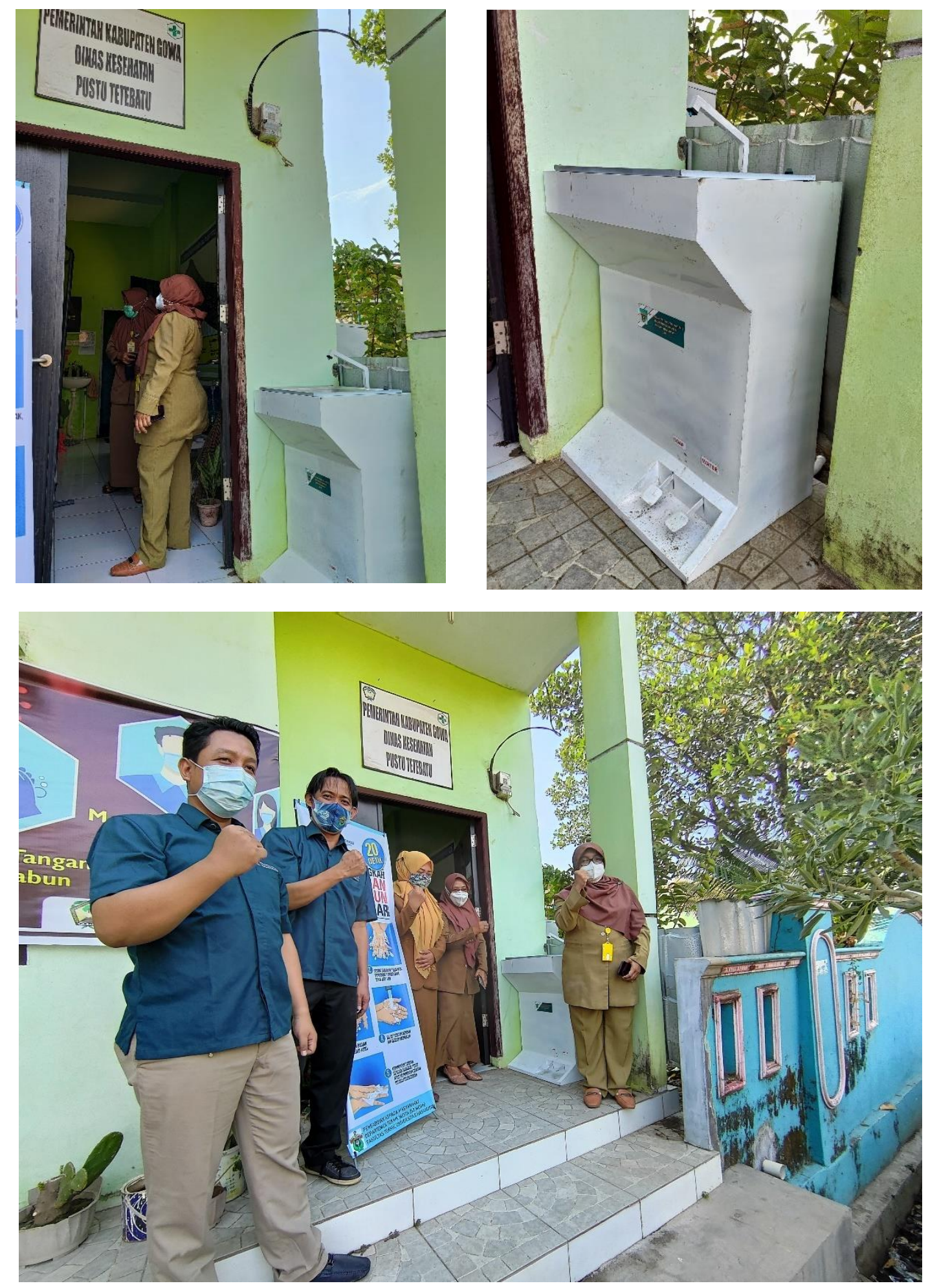

Gambar 4. Penyerahan dan Penggunaan wastafel portabel pada Puskesmas.

Selain dengan alat cuci tangan portable, turut dipasang pula beberapa banner panduan cara cuci tangan dari Gerakan Masyarakat Hidup Sehat (Germas) Kementrian Kesehatan sebagai sarana edukasi hidup sehat di Pesantren, Sekolah dan Pustu tersebut. Kegiatan ini dilaksanakan sebagai 
upaya pencegahan penyebaran Covid-19 di pesantren, sekolah dan puskesmas dalam memasuki masa "new normal" saat ini.

\section{Kesimpulan}

Pencegahan dan minimalisasi penyebaran Covid-19 pada masyarakat dapat dicapai dengan peyediaan alat cuci tangan portabel ini. Tempat yang biasanya menjadi pusat penyebaran virus seperti Sekolah dan Puskesmas yang menjadi sasaran dari kegiatan ini telah dibekali dengan alat cuci tangan portabel sehingga akan membantu masyarakat untuk hidup sehat. Edukasi pada masyarakat dilingkungan pesantren, sekolah dan Puskesmas tentang bahaya Covid-19 dan upaya pencegahan dilakukan dalam bentuk media komunikasi visual berupa banner cara cuci tangan yang benar dari Gerakan masyarakat hidup sehat (Germas).

\section{Ucapan Terima Kasih}

Ucapan terima kasih ditujukan kepada Fakultas Teknik Universitas Hasanuddin yang telah mendukung pendanaan kegiatan ini melalui Skim Pengabdian Masyarakat Laboratorium Based Education ( $L B E$ ) 2020. Ucapan terima kasih juga ditujukan kepada Program Studi Magister Departemen Teknik Mesin Fakultas Teknik Universitas Hasanuddin yang telah mempercayakan pengelolaan program pengabdian masyarakat ini. Penghargaan juga disampaikan kepada Mitra pengabdian, Pondok Pesantran Yatama, TK Mustika dan Pustu Yatama. Rasa terima kasih yang sebesar-besarnya pada semua pihak yang mendukung terlaksanannya Program Pengabdian kepada Masyarakat ini.

\section{Daftar Pustaka}

Laporan harian kasus Covid-19 BNPB, Gugus Tugas Nasional Percepatan Penanganan Covid19. Akses web 29 Juni 2020 https://bnpb-inacovid19.hub.arcgis.com/

PEDOMAN PENCEGAHAN DAN PENGENDALIAN CORONAVIRUS DISESASE (COVID19), Kementrian Kesehatan Republik Indonesia, 23 Maret 2020

"Perbandingan Kasus COVID-19 di Makassar Sebelum dan Setelah PSBB", IDN TIMES SULSEL, Akses berita 29 Juni 2020 https://sulsel.idntimes.com/news/sulsel/ashrawimuin/perbandingan-kasus-covid-19-di-makassar-sebelum-dan-setelah-psbb/2

Update data harian Covid-19 Provinsi Sulawesi Selatan, Sulsel Tanggap Covid-19. Akses data 29 Juni 2020 https://covid19.sulselprov.go.id/

Cui J, Li F, Shi Z-L. Origin and evolution of pathogenic coronaviruses. Nat Rev Microbiol 2019;17(3):181-92.

Lai C-C, Shih T-P, Ko W-C, Tang H-J, Hsueh P-R. Severe acute respiratory syndrome coronavirus 2 (SARS-CoV-2) and corona virus disease-2019 (COVID19): the epidemic and the challenges. Int J Antimicrob Agents 2020;105924. 